\title{
CD11A Expressing Cell Count
}

National Cancer Institute

\section{Source}

National Cancer Institute. CD11A Expressing Cell Count. NCI Thesaurus. Code C105439.

The determination of the amount of the CD11a expressing cells in a sample. 